\title{
Covid-19 Döneminde Evden Çalıșmada Algılanan İș Verimliliği ve Öncülleri Arasındaki İlişkiler: Banka Çalışanları ve Öğretmenler Üzerine Karşılaştırmalı Bir Araştırma
}

\section{Dilek TAȘKIN ${ }^{1}$}

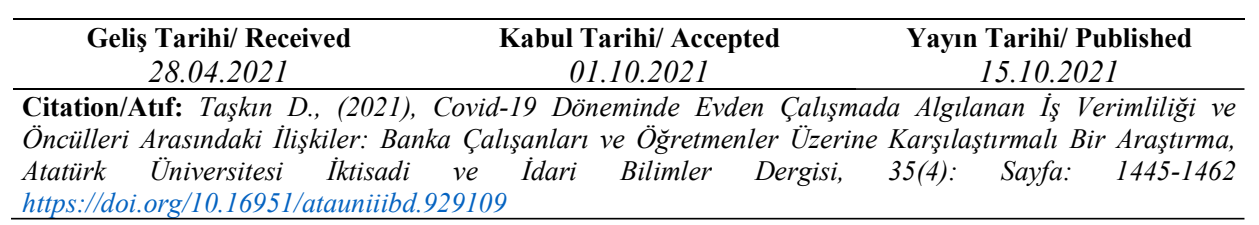

Öz: COVID-19 pandemisi dünyada ve Türkiye'de 2020 yılının Mart ayından bu yana çeşitli sektörleri etkilemektedir. Türkiye'de bu etkinin azaltılması amacıyla, pandeminin başladığı andan itibaren özellikle fiziksel teması ortadan kaldırmaya yönelik önlemler alınmıştır. Bu durumdan başta eğitim kurumları (MEB'e bağlı) ve bankalar etkilenmiştir. Her iki hizmet sektöründe de aralıklarla da olsa daha önceden uygulanmayan veya tercih edilmeyen tam evden çalışma veya kısmi evden çalışma sistemine geçiş söz konusu olmuştur. Bu durum da, insan kaynakları yönetimi açısından önemli bir kavram olan iş verimliliğini olumsuz etkileyebilmektedir. Bu çalıșmanın amacı, pandemi döneminde evden çalıșma sistemini en az 3 ay deneyimlemiş ögretmenler ve banka çalışanlarının algılanan iş verimliliği ve öncülleri (aile iş çatışmașı, rol çatışması ve algılanan stres) arasındaki ilişkileri incelemek, her iki çalışan grubunu karşılaştırmak ve insan kaynakları yönetimi uygulamaları açısından önerilerde bulunmaktır. Araştırmanın verileri 2021 yılının Mart ve Nisan aylarında Bursa şehir merkezinde ikamet eden banka çalışanlarından ve öğretmenlerden toplanmıştır. Araștırmada kartopu örnekleme yöntemi kullanılmıș ve veriler online anket tekniği ile toplanmıștır. Toplamda 336 adet analize uygun anket verisi elde edilmiştir. Banka çalışanları örneklemi için elde edilen sonuçlara göre, algılanan iş verimliliğinin en önemli öncülünün aile iș çatışması olduğu bulunmuştur. Algılanan iş verimliliğinin diğer önemli öncülleri de sırasıyla, rol çatışması ve algılanan stres olarak tespit edilmiştir. Buna karşın, öğretmen örneklemi için elde edilen bulgular incelendiğinde, algılanan iş verimliliğinin en önemli öncülünün algılanan stres olduğu tespit edilmiştir. Algılanan stresin öncüllerine bakıldığında benzer şekilde en önemli öncüllerin aile iş çatışması ile rol çatışması olduğu bulunmuştur.

Anahtar Kelimeler: COVID-19, Evden Çalışma, Algılanan İş Verimliliği, Aile İş Çatışması, Rol Çatışması, Algılanan Stres, Öğretmenler, Banka Çalışanları

\section{The Relationships among Perceived Work Productivity and its Antecedents During Covid-19: A} Comparative Research on Bank Employees and Teachers

Abstract: COVID-19 pandemic has started to influence various sectors since March of 2020 both in the World and Turkey. Since the beginning of the pandemic, many precautions has been taken to eliminate physical contact in order to decrease the influence in Turkey. Education institutions (that belong to MEB) and banks have been affected by this situation. Working from home system was used for all of the employees or some of the employees in both services sectors where working from home system was generally not preferred or used before. Thus, this new situation may negatively influence work productivity which is an important concept from the perspective of human resources management. The aim of this study is to investigate the relationships among perceived work productivity and its antecedents (family work conflict, role conflict and perceived stress) on teachers and bank employees who have experienced working from home at least 3 months in the pandemic, to compare both employee groups and to propose suggestions from the perspective of human resource. The data were collected from bank employees and teachers who live in Bursa city center in the months of March and April 2021. Sampling method was chosen as snowball sampling and online survey was used as the data collection technique. Totally, 336 survey data were obtained for the analysis. Family work conflict was found

${ }^{\text {I}}$ Öğr. Gör., Bursa Uludă̆ Üniversitesi, Orhaneli Meslek Yüksekokulu, Büro Hizmetleri ve Sekreterlik Bölümü, dilektaskin@uludag.edu.tr,https://orcid.org/0000-0003-2379-9698 
Covid-19 Döneminde Evden Çallşmada Algllanan İş Verimliliği ve Öncülleri Arasindaki İlişkiler: Banka Çalışanları ve Öğretmenler Üzerine Karşılaş̧tırmalı Bir Araştırma

to be the most important antecedent of perceived work productivity according to the results of bank employees sample. Role conflict and perceived stress were the other important antecedents of perceived work productivity for the bank employees sample. On the contrary, perceived stress was found to be the most important antecedent of perceived work productivity according to the results of teachers sample. Family work conflict and role conflict were found to be the important antecedents of perceived stress for the teachers sample.

Keywords: COVID-19, Working from Home, Perceived Work Productivity, Family Work Conflict, Role Conflict, Perceived Stress, Teachers, Bank Employees

Jel Codes: M10, M12, M19

\section{EXTENDED SUMMARY}

\section{Research Problem}

The world is facing a crucial situation nowadays. It is a serious health issue that is named as COVID-19 pandemic. It is serious because it has impacts both on health and business. COVID-19 pandemic has started to influence various sectors since March of 2020 both in the world and Turkey.Since the beginning of the pandemic, many precautions has been taken in order to decrease physical contact and to avoid spreading of virus in Turkey. The first precaution was applied on education system by the government and banking by the managers of banks. Thus, education institutions and banks have been affected by this situation. Working from home system was used for all of the employees or some of the employees in both services sectors where working from home system was generally not preferred or used before. Thus, this new situation may negatively influence work productivity which is an important concept from the perspective of human resources management. The aim of this study is to investigate the relationships among perceived work productivity and its antecedents (family work conflict, role conflict and perceived stress) on teachers and bank employees who have experienced working from home at least 3 months in the pandemic, to compare both employee groups and to propose suggestions from the perspective of human resources.

\section{Research Questions}

Does role conflict has an impact on family work conflict?

Does role conflict has an impact on perceived stress?

Does role conflict has an impact on perceived work productivity?

Does family work conflict has an impact on perceived stress?

Does family work conflict has an impact on perceived work productivity? Does perceived stress has an impact on perceived work productivity?

\section{Methodology}

Quantitative research methodology is used in this study. The data collection tool is the questionnaire. The data were collected from bank employees and teachers who live in Bursa city center in the months of March and April 2021. The sample were the people who have experienced working from home at least 3 months in the pandemic. Sampling method was chosen as snowball sampling and 
online survey was used as the data collection technique. Totally, 336 survey data were obtained for the analysis.

\section{Results and Conclusions}

According to the research findings of bank employees, family work conflict was found to be the most important antecedent of perceived work productivity with a $-0,35$ path coefficient. The other important antecedents of perceived work productivity were found to be role conflict and perceived stress with path coefficients $-0,29$ and $-0,19$ respectively.

According to the research findings of teachers, perceived stress was found to be the most important antecedent of perceived work productivity with a $-0,22$ path coefficient. The important antecedents of perceived stress were found to be family work conflict and role conflict with path coefficients $-0,43$ and $-0,29$ respectively.

The analysis results include important similarities for both the teachers and bank employees samples. It was found that family work conflict and role conflict were very important antecedents of perceived work productivity for both the samples. Thus, human resources managers and the managers of these employees should take these variables into consideration. Human resources management should not allow the role conflict among employees by defining written tasks and assigning them to the employees clearly. The organisation structure should be well organised and the authority and responsibility of the employees should be very clearly set. In addition, the communication channels between employees and their managers shoud be transparent in the coronavirus pandemic.

\section{Giriş}

COVID-19 pandemisi Türkiye'de 2020 y1lının Mart ayı başlarından itibaren gerek kamu sektörünü gerekse de özel sektörü etkilemeye başlamıştır. Özellikle fiziksel mesafenin ve fiziksel hareketliliğin en aza inmesi için bir dizi önlem alınmıştır. Alınan önlemlerin başında belirli sektörlerde "evden çalışma" sistemine geçiş gelmektedir. Esnek çalışma modellerinden biri olan uzaktan ya da evden çalışma sistemi özellikle pandemi döneminde hem halk sağlığını korumak hem de sürecin ekonomi üzerindeki olumsuz etkilerini hafifletmek açısından önem kazanmıştır. Pandeminin başladığı günden bu yana ülkemizde evden çalışma sistemini benimseyen sektörlerin öncüsü olarak eğitim sektörü ve bankacılık sektörü gelmektedir. Her iki sektörde de kısmen de olsa ya da aralıklarla evden çalışma sistemi uygulanmış ve halen de uygulanmaya devam etmektedir.

Eğitim ve bankacılık hizmet sektörlerinde özellikle kişisel temasın yüksek seviyede olması nedeniyle, COVID-19 pandemisi tarafindan en fazla etkilenen sektörlerden olmuştur. Yüz yüze yapılan faaliyetler yerini dijital teknolojilere 
Covid-19 Döneminde Evden Çallşmada Algllanan İş Verimliliği ve Öncülleri Arasindaki İlişkiler: Banka Çalışanları ve Öğretmenler Üzerine Karşılaş̧tırmalı Bir Araştırma

bırakmış ve bu teknolojiler ile çalışanlar evden tamamen ya da kısmen çalışmışlardır (Chadee vd., 2021: 1-2).

Pandeminin başlarında COVID-19 virüsünün yayılmasını engellemek için gereken sosyal mesafe kısıtlamaları altında eğitim ve bankacılık gibi hizmet sektörlerinde evden çalışma sistemi hızla "yeni normal" olmuştur. Evden çalışma, virüsün işyerinde, çalışanlar arasında ve çalışanlar ile müşteriler arasında potansiyel olarak yayılmasını ortadan kaldırmakla birlikte, aynı zamanda işyerine gidip gelmeyle ilgili sosyal iletişimi de azaltmaktadır (Dockery ve Bawa, 2020: 1).

COVID-19 pandemisi genel olarak insan kaynakları yönetimi için düşünce sınırlarını genişletmeyi gerektiren yeni bir durum oluşturmuştur. İnsan kaynakları yöneticilerinin, çalışanlarının iş ve sosyal çevrelerinde meydana gelen radikal değişikliklere uyum sağlamasına ve mücadele etmesine yardımcı olması gerekmektedir. Örneğin, eskiden bir organizasyonun fiziksel sınırları içinde çalışarak zamanlarının çoğunu geçiren çalışanlar, bu dönemde evden çalışma ortamına göre kendilerini uyarlamak zorunda kalmaktadırlar. Giderek iș ve özel hayatı birbirinden ayırt edebilme konusundaki yetersizlik çalışanlar için iş ve aile katmanları arasındaki hatların bulanıklaşmasına neden olmaktadır (Carnevale vd., 2020: 183). İşi eve getirmek ve daha uzun çalışma saatleri, çalışan için işaile çatışması duygularını şiddetlendirebilir (Dockery ve Bawa, 2020: 3). İşlerini ve kişisel yaşamlarını doğal olarak ayırmayı tercih eden çalışanlar açısından dahi mevcut şartlar uygun değildir. Eğitim kurumları dönem dönem kapanmakta ve çocuklu aileler için kreş de artık bir seçenek olmamaktadır. Bu durum da çalışan aile bireylerine ek yükler bindirmektedir (Giurge ve Bohns, 2020).

Evden çalışma esnasında birçok çalışan iş ve sosyal yaşamlarını yürütürken bir denge oluşturmaya çalışırlar. Zamanlarını işlerini yapma ve sosyal yaşamları için paylaştırırlar. Erkek çalışanlar için, iş-yaşam dengesi net bir şekilde hissedilir. Erkek çalışanlar evden çalışmada dengeyi iyi bir şekilde sağlayabilirler ve geri kalan zamanı ailenin diğer bireyleri, meslektaşları ile bazı dijital iletişim araçları ile sosyal yaşamları için kullanabilirler. Ancak, evli olan kadın çalışanlar için bu geçerli olmamaktadır. Evli kadın çalışanlar için iş-yaşam dengesi, zamanlarını iş ve sosyal yaşamları arasında ayırmada zorluk yaşadıklarından dolayı tam olarak sağlanamaz. Bunun sebebi de ev içinde daha fazla görevlere sahip olmalarıdır (çocuk bakımı, yemek hazırlama vb.). Dolayısıyla, evden çalışmanın aile bireylerini faklı etkilediği söylenebilir (Mustajab vd., 2020: 16).

COVID-19 pandemisi ayrıca istihdamı derinden etkilemekte ve insanlar için kariyer iniş çıkışları yaratabilmektedir. İnsan kaynakları yönetiminin evden çalışma sistemi nedeniyle artacak işgücü stresi ile mücadele etmesini öğrenmesi de gerekmektedir (Gigauri, 2020: 2). Sözü edilen tüm bu durumlar insan kaynakları yönetimi açısından son derece önemli bir kavram olan iş verimliliğini 
olumsuz etkileyebilmektedir. Türkiye'de pandemi öncesinde evden çalışma sisteminin sistematik olarak uygulanmadığı ve tercih edilmediği iki sektörün çalışanları (MEB'e bağlı öğretmenler ve banka çalışanları) 2020 Mart ayından itibaren kısmen veya aralıklarla bir anda evden çalışma sistemine geçiş yapmıştır. $\mathrm{Bu}$ durumun ne kadar süreceği belli olmamakla beraber, gelecekte benzer durumlarla karşılaşılma olasılığına karşı işletmelerin insan kaynakları yönetimi açısından hazırlıklı olması gerekmektedir. $\mathrm{Bu}$ çalışma, bu önemli konuyu pandemi döneminde niceliksel olarak araştırması yönüyle, hem yerli literatüre özgün katk1 sunmakta hem de eğitim ve banka sektörüne pratik sonuçlar sağlamaktadır. Özetle ifade edilmesi gerekirse, bu çalışmanın amacı pandemi döneminde evden çalışma sistemini en az 3 ay deneyimlemiş öğretmenler ve banka çalışanlarının algılanan iş verimliliği ve öncülleri (aile iş çatışması, rol çatışması ve algılanan stres) arasındaki ilişkileri incelemek ve insan kaynakları uygulamaları açısından önerilerde bulunmaktır. Makalede öncelikle oluşturulan kavramsal modelin unsurları tanımlanmakta, bu unsurların önemi ve birbirleriyle olan ilişkileri literatüre dayalı olarak vurgulanmaktadır. Makalede daha sonra araştırma kısmının aşamaları yer almaktadır. Burada da sırasıyla araştırma amacı, ölçeği, örneklemi, modeli, hipotezleri ve araştırmanın bulguları başlıklarına yer verilmektedir.

\section{Kavramsal Modelin Unsurları}

Çalışmanın amacını gerçekleştirmek üzere oluşturulan kavramsal modele ait öncüller, aile iş çatışması, rol çatışması ve algılanan stres olarak belirlenmiştir. Pandemi döneminin özelliği nedeniyle söz konusu değişkenler algılanan iş verimliliğini etkileyen önemli öncüller olarak karşımıza çıkmaktadır. Bunlar aşağıda kısaca açıklanmaktadır.

Aile ve iş kavramları arasındaki çatışma, kendi içerisinde iki farklı durumu içeren genel bir kavram olarak ifade edilebilir. Bunlar, aileye ayrılan kaynakların bireyin iş unsurları tarafından engellenmesi (işin aileyle çatışması-İAÇ) ya da bireyin işine ayırdığı kaynakların aile unsurlarınca engellenmesidir (ailenin işle çatışması-AİÇ). Özetle, iş-aile çatışmasında işten aileye yansıyan sorunlar nedeniyle oluşan bir çatışma hali mevcutken, aile-iş çatışmasında aileden işe yansıyan sorunlar nedeniyle çatışmalar oluşmaktadır. Kişinin iş ve aile rol gereklerinin dengelenmemesi durumunda iş-aile çatışması ya da aile-iş çatışması yaşanmaktadır. Bu kapsamda algılanan talepler kişinin zamanını ve enerjisini sınırlamakta ve böylece çatışma ortaya çıkmaktadır (Fırat ve Cula, 2016:147).

Netemeyer ve diğerlerine göre (2004: 50) aile iş çatışması, iş ile ilgili sorumlulukları yerine getirme aşamasında aile tarafından gelen talepler üzerine oluşan bir rol çatışması biçimi olarak ifade edilebilir. Bir başka çalışmaya göre, aile-iş çatışması ise çalışanın işe ilişkin sorumluluklarının ailevi sorumluluklar nedeniyle yerine getirilmesinde yaşanan zorluk olarak tanımlanmaktadır (Aydın ve Ünnü, 2020: 16). Belirtildiği üzere, aile ve iş kavramları arasındaki çatışma 
Covid-19 Döneminde Evden Çallşmada Algllanan İş Verimliliği ve Öncülleri Arasindaki Ilisşkiler: Banka Çalışanları ve Öğretmenler Üzerine Karşılaş̧tırmalı Bir Araş̧tırma

iki yönlüdür. Literatüre bakıldığında iş-aile çatışmasının daha yüksek düzeyde olduğu ifade edilmektedir (Colombo ve Ghislieri, 2008: 38). Ancak, özellikle COVID-19 pandemi döneminde evden çalışan bireylerde aile iş çatışmasının daha ön plana çıktığı düşünülmektedir.

Algılanan stres kavramı, bireylerin olaylarla baş edebilme yeteneklerine göre yaşamlarındaki durumları algılama biçimi olarak ifade edilebilir (Taylor, 2015: 90). Günümüzde birey, iş- aile ve sosyal çevre üçgeni arasında yaşantısını sürdürmekte, zaman zaman iş hayatı iş dışındaki yaşamı etkilemekte ya da tam tersi durumla karşı karşıya kalmaktadır. Belirli sorumluluk kademesine gelen kişiler, iş ve aile yaşamlarını dengelemek, her iki yaşantıyı da bir sosyal ortamda yürütmek zorundadırlar. İş yaşamı ile aile yaşamının gerektirdikleri ve ortaya çıkan rol çatışması kişi üzerinde strese yol açmaktadır. Mesleki stresin en önemli bileşenlerinden birisi ve hem işgörenler hem de işverenler açısından önemli olanı, iş aile yaşamı ilişkisidir. Her ne kadar, çalışmalar, iş yaşamındaki stresin aile üzerindeki etkisinin daha fazla olduğunu ortaya koysa da, daha önce de belirtildiği gibi bu ilişki çift yönlüdür. Kişisel yaşam ve iş ortamındaki birden fazla ve çatışma halindeki rollerin gereklilikleri potansiyel stres kaynaklarıdır (Küçükusta, 2007: 63). İşin eve getirilmesi başlı başına bir potansiyel çatışma arttırıcıdır. Çalışanların iş ortamından soyutlanması ve uzun çalışma saatleri de evden çalışmanın negatif etkilerindendir ve strese neden olmaktadır (Dockery ve Bawa, 2020: 2).

Rol çatışması, farklı iş beklentileri arasında uyuşmazlık söz konusu olduğunda ortaya çıkar. Rol çatışması öz bir ifade ile uyumsuz iş gereksinimleri olarak tanımlanabilir. Bu gereksinimler işin algılanan uyuşmazlığı nedeniyle negatif duygusal tepkiler oluşturur. Rol çatışması, çalışan, uyuşmayan iş gereksinimleri ile karşılaştığında, yapmak istemediği faaliyetler yapması gerekiyorsa ve bu faaliyetlerin işinin bir parçası olduğunu düşünmüyorsa meydana gelir. Çalışanlar rol çatışması yaşadığında yüksek düzeyde stres algilarlar (Parvaiz vd., 2015: 54; Soto-Rubio, 2020: 2).

Normal zamanlarda, iş ve iş dışı roller arasındaki sınırlar birçok insanın günlük hayatında karşılaşacağı potansiyel gerginliğin kaynaklarıdır. Ayrıca, 2020 yılının Mart ayı ortalarından itibaren hükümetlerin sosyal mesafe için uyguladıkları ve önerdikleri çalışma biçimlerinden biri olan evden çalışma da işiş dışı sınırların birbirine karışmasına neden olarak rol çatışmasına zemin hazırlamıştır (Schieman vd., 2021: 1).

İş verimliliği kavramı bir bireyin işini yapmada ne kadar etkili ve etkin olduğu ile ilgilidir. İş verimliliği, bireyin işinde zamanı kullanmada, fiziksel taleplerin üstesinden gelmede, meslektaşları ve iş çevresi ile ilişsilerde, işin kalitesi ve miktarında ne kadar etkin olduğu şeklinde tanımlanabilir. Bir başka tanıma göre, iş verimliliği girdi birimleri tarafından üretilen çıktı miktarının bir 
ölçümüdür. Bir başka ifade ile bireyin işinde nitelik ve nicelik olarak işleyiş düzeyinin bir ölçümüdür (Tentama vd., 2019: 2).

\section{Araştırmanın Metodolojisi}

Araştırmanın metodolojisi kısmında sırasıyla araştırmanın amacı, araştırmanın ölçeği ve örneklemi, araştırmanın modeli ve hipotezleri ile araştırmanın bulguları alt başlıkları yer almaktadır.

\subsection{Araştırmanın Amacı}

$\mathrm{Bu}$ araştırmanın amacı devam etmekte olan pandemi döneminde evden çalışmakta olan veya en az 3 ay çalışmış banka çalışanları ve öğretmenler açısından "algılanan iş verimliliği" ve öncülleri (aile iş çatışması, rol çatışması ve algılanan stres) arasındaki ilişkileri yapısal eşitlik modelleme ile test etmek ve çıkarımlarda bulunmaktır.

\subsection{Araştırmanın Ölçeği ve Örneklemi}

Araştırmanın ölçeği toplam 15 ifadeden oluşmaktadır. Araştırma modelindeki boyutlar, "aile iş çatışması", "rol çatışması", "algılanan stres" ve "algılanan iş verimliliği’"dir. Araştırmada kullanılan aile iş çatışması ölçeği, Netenmeyer, Boles ve McMurrian (1996) tarafından geliştirilen iş-aile yaşam çatışması ölçeğine dayanmaktadır. Netenmeyer, Boles ve McMurrian (1996) tarafindan geliştirilen iş-aile yaşam çatışması ölçeği iş-aile çatışması ve aile-iş çatışması düzeylerini ölçmeyi amaçlayan iki alt ölçekten oluşmaktadır. Her iki ölçek de çatışma durumunu belirlemeye yönelik 5'er maddelik yargı cümlelerinden oluşmaktadır. $\mathrm{Bu}$ çalışmada araştırma amacına uygunluğu nedeniyle aile iş çatışması ölçeği kullanılmıştır (Furat ve Cula, 2016: 150).

Araştırmada algılanan stresi ölçmeye yönelik 4 ifade bulunmaktadır. Ölçek Cohen, Kamarck ve Mermelstein tarafından geliştirilmiştir. Bu ölçüm aracı, bireyin yaşamındaki olayların ne düzeyde stresli olarak algılandığı ile ilgilidir (Küçükusta, 2007: 140). Algılanan stres ölçeğinin üç biçimi vardır. Bunlardan ilki 14 ifadeli orijinal ölçektir. Daha sonra 10 ifadeli biçimi oluşturulmuş olup, 4 ifadeli biçimi de son olarak geliştirilmiştir (Lee, 2012: 121).

Araştırma modelinin diğer değişkeni olan rol çatışmasının ölçümü için Parvaiz vd., (2015) çalışmasında yer alan ölçek uyarlanmıştır. Araştırma modelinde yer alan algılanan iş verimliliği değişkeninin ölçümü için ise, pandemi döneminde evden çalışma ile ilgili Feng ve Savani adlı araştırmacıların literatürden pandemi dönemi özelliklerine uygun olması için uyarladıkları algılanan iş verimliliği ölçeği kullanılmıştır (Feng ve Savani, 2020: 725-726).

Araştırmanın verileri 2021 yılının Mart ve Nisan aylarında Bursa şehir merkezinde ikamet eden ve pandemi döneminde en az 3 ay evden çalışmış banka çalışanlarından ve öğretmenlerden toplanmıştır. Araştırmada kartopu örnekleme yöntemi kullanılmış ve veriler online anket tekniği ile toplanmıştır. Toplamda 336 adet analize uygun anket verisi elde edilmiştir. 
Covid-19 Döneminde Evden Çalışmada Algılanan Işs Verimliliği ve Öncülleri Arasındaki İlişkiler: Banka Çalışanları ve Öğretmenler Üzerine Karşılaştırmalı Bir Araştırma

\subsection{Araştırmanın Modeli ve Hipotezleri}

Araştırmanın modeli ve hipotezleri Şekil 1'de gösterilmiştir. Araştırma modeli aile iş çatışması, rol çatışması, algılanan stres ve algılanan iş verimliliği boyutları ve bu boyutların arasındaki ilişkilerden oluşmaktadır.

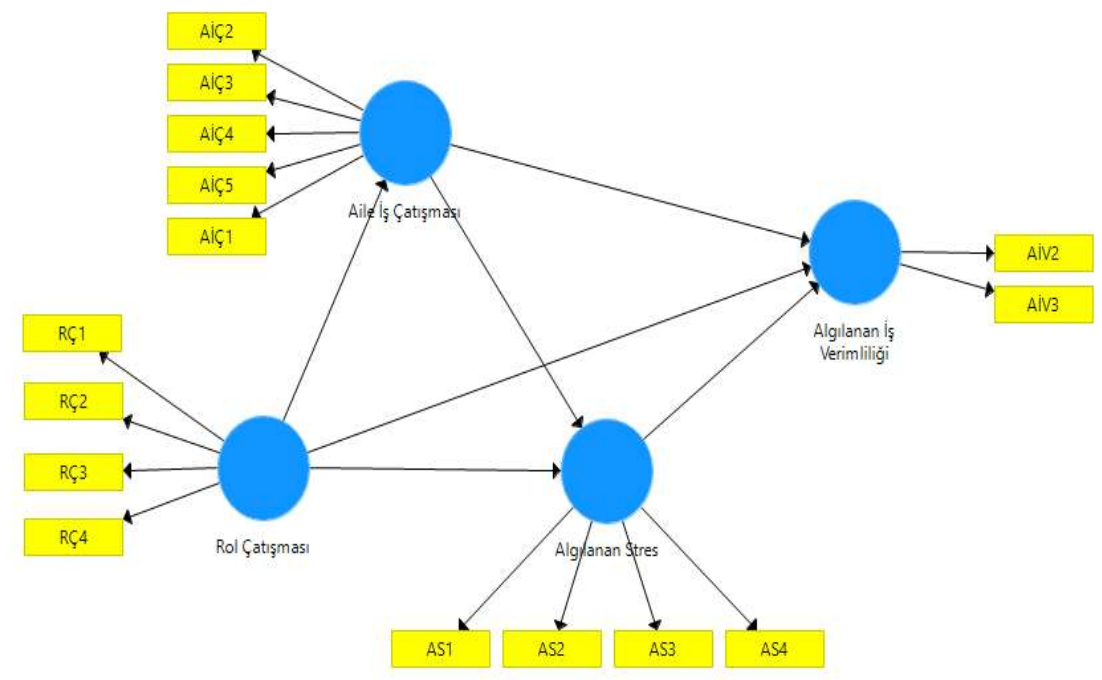

Şekil 1. Araştırma Modeli

Araştırma hipotezleri aşağıda ifade edilmiştir: vardir.

$\mathrm{H}_{1}$ : Rol çatışması değişkeninin aile iş çatışması değişkeni üzerinde etkisi

$\mathrm{H}_{2}$ : Rol çatışması değişkeninin algılanan stres değişkeni üzerinde etkisi vardir.

$\mathrm{H}_{3}$ : Rol çatışması değişkeninin algılanan iş verimliliği değişkeni üzerinde etkisi vardır. vardir.

$\mathrm{H}_{4}$ : Aile iş çatışması değişkeninin algılanan stres değişkeni üzerinde etkisi

$\mathrm{H}_{5}$ : Aile iş çatışması değişkeninin algılanan iş verimliliği değişkeni üzerinde etkisi vardır. etkisi vardır.

$\mathrm{H}_{6}$ : Algılanan stres değişkeninin algılanan iş verimliliği değişkeni üzerinde

\subsection{Araştırmanın Bulguları}

\subsubsection{Katılimcilarin Profilleri}

Araştırmaya katılan deneklerin profillerine dair bilgiler Tablo 1'de sunulmuştur. 
Tablo 1. Katılımcıların Profilleri

\begin{tabular}{|c|c|c|c|c|c|}
\hline Cinsiyet & Frekans & $\%$ & Meslek & Frekans & $\%$ \\
\hline Kadın & 232 & 69 & Bankacı & 170 & 50,6 \\
\hline Erkek & 104 & 31 & Öğretmen & 166 & 49,4 \\
\hline Toplam & 336 & & Toplam & 336 & \\
\hline Yaş & Frekans & $\%$ & $\begin{array}{l}\text { Medeni } \\
\text { Durum }\end{array}$ & Frekans & $\%$ \\
\hline $22-30$ & 74 & 22 & Bekâr & 105 & 31,2 \\
\hline $31-40$ & 167 & 49,7 & Evli & 231 & 68,8 \\
\hline $41-50$ & 73 & 21,7 & Toplam & 336 & \\
\hline 50 üzeri & 22 & 6,6 & & & \\
\hline Toplam & 336 & & & & \\
\hline $\begin{array}{l}\text { Çocuk } \\
\text { Sayısı }\end{array}$ & Frekans & $\%$ & $\begin{array}{l}\text { Hane Halkı } \\
\text { Sayısı (Denek } \\
\text { Hariç) } \\
\end{array}$ & Frekans & $\%$ \\
\hline 0 & 119 & 35,4 & 1 & 49 & 14,6 \\
\hline 1 & 110 & 32,7 & 2 & 125 & 37,2 \\
\hline 2 & 99 & 29,5 & 3 & 106 & 31,5 \\
\hline 2'den fazla & 8 & 2,4 & 3'ten fazla & 56 & 16,7 \\
\hline Toplam & 336 & & Toplam & 336 & \\
\hline $\begin{array}{l}\text { Pandemi } \\
\text { Döneminde } \\
\text { İş Yükünüzz } \\
\text { Arttı Mı? }\end{array}$ & Frekans & $\%$ & $\begin{array}{l}\text { Evden } \\
\text { Çalışmayı } \\
\text { Pandemi } \\
\text { Sonrasında } \\
\text { Tercih Eder } \\
\text { Misiniz? } \\
\end{array}$ & Frekans & $\%$ \\
\hline Evet & 260 & 77,4 & Evet & 106 & 31,5 \\
\hline Hayır & 76 & 22,6 & Hayır & 230 & 68,5 \\
\hline Toplam & 336 & & Toplam & 336 & \\
\hline
\end{tabular}

Araştırmada toplanan verilerin dağılımına bakıldığında, katılımcıların \%69'u kadın, \%31'i ise erkektir. Katılımcıların yaklaşık yarısı banka çalışanları yarısı da öğretmenlerdir. Katılımcıların yaş dağılımına bakıldığında yarıya yakınının 31-40 arası olduğunu göstermektedir. Katılımcıların \%68,8'i evli olup, \%31,2'si bekârdır. Dul kategorisi ayrıca araştırılmamış olup, onlar da bekâr grubu içinde yer almaktadır. Katılımcıların \%35,4'ünün çocuğu yoktur. Geri kalan katılımcıların en az 1 çocuğu vardır. Katılımcıların hane halkı sayısı dağılımına bakıldığında (kendisi hariç) en yüksek oran \%37,2 ile 2'dir. Araştırmanın pandemi dönemine ilişkin iki önemli sorusunun yanıtlarının dağılımı ise şöyledir. Katılımcıların \%77,4'ü pandemi döneminde iş yükünün arttığını belirtmiştir. Bir diğer sorunun yanıt dağılımında ise, katılımcıların $\% 68,5$ 'i pandemi sonrasında evden çalışmayı tercih etmeyeceklerini ifade etmişlerdir. 
Covid-19 Döneminde Evden Çalışmada Algllanan İş Verimliliği ve Öncülleri Arasındaki İlişkiler: Banka Çalışanları ve Öğretmenler Üzerine Karşılaştırmalı Bir Araştırma

\subsubsection{Geçerlilik ve Güvenilirlik Analizi}

Araştırma modelindeki hipotezlerin test edilmesi öncesinde, Smart-PLS yazılımı ile boyutların geçerlilik ve güvenilirlik analizi yapılmıştır. Elde edilen sonuçlar, banka çalışanları örneklemi için Tablo 2'de, öğretmen örneklemi için ise Tablo 3'te verilmiştir. Her bir boyutun gözlenen değişkenlerine ait faktör yükleri (outer loadings) ve sirasiyla Cronbach's Alpha, AVE (Average Variance Extracted) ve CR (Composite Reliability) değerleri ilgili tablolarda yer almaktadir.

Tablo 2. Yapısal Güvenilirlik ve Geçerlilik (Bankacı Örneklemi)

\begin{tabular}{|c|c|c|c|c|c|}
\hline Boyut & İfade & $\begin{array}{c}\text { Outer } \\
\text { Loading }\end{array}$ & $\begin{array}{c}\text { Cronbach's } \\
\text { Alpha }\end{array}$ & AVE & CR \\
\hline \multirow{5}{*}{ Aile İş̧ Çatışması } & AİÇ1 & 0,75 & \multirow{5}{*}{0,90} & \multirow{5}{*}{0,72} & \multirow{5}{*}{0,92} \\
\hline & AİÇ2 & 0,81 & & & \\
\hline & AİÇ3 & 0,88 & & & \\
\hline & AİÇ4 & 0,88 & & & \\
\hline & AİÇ5 & 0,90 & & & \\
\hline \multirow{4}{*}{ Alg1lanan Stres } & AS1 & 0,85 & \multirow{4}{*}{0,88} & \multirow{4}{*}{0,75} & \multirow{4}{*}{0,92} \\
\hline & AS2 & 0,91 & & & \\
\hline & AS3 & 0,79 & & & \\
\hline & AS4 & 0,88 & & & \\
\hline \multirow{2}{*}{$\begin{array}{l}\text { Algılanan İş } \\
\text { Verimliliği }\end{array}$} & AIV2 & 0,93 & \multirow{2}{*}{0,85} & \multirow{2}{*}{0,87} & \multirow{2}{*}{0,93} \\
\hline & AIV3 & 0,93 & & & \\
\hline \multirow{4}{*}{ Rol Çatışması } & RÇ1 & 0,79 & \multirow{4}{*}{0,72} & \multirow{4}{*}{0,55} & \multirow{4}{*}{0,83} \\
\hline & $\mathrm{RÇ2}$ & 0,75 & & & \\
\hline & $\mathrm{RÇ3}$ & 0,73 & & & \\
\hline & $\mathrm{RÇ} 4$ & 0,67 & & & \\
\hline
\end{tabular}

Banka çalışanları örnekleminin güvenilirlik ve geçerlilik sonuçlarının olduğu Tablo 2'ye bakıldığında Cronbach's Alpha değerlerinin 0.72 ile 0.90 arasında, CR değerlerinin 0.70'in ve AVE değerlerinin 0.50'nin üzerinde olduğu görülebilir. Bu değerler uygun değerler olarak kabul edilir (Jung vd., 2017: 145).

Tablo 3. Yapısal Güvenilirlik ve Geçerlilik (Öğretmen Örneklemi)

\begin{tabular}{|c|c|c|c|c|c|}
\hline Boyut & İfade & $\begin{array}{c}\text { Outer } \\
\text { Loading }\end{array}$ & $\begin{array}{c}\text { Cronbach's } \\
\text { Alpha }\end{array}$ & AVE & $\mathbf{C R}$ \\
\hline \multirow{5}{*}{ Aile İş Çatışması } & AİÇ1 & 0,67 & \multirow{5}{*}{0,87} & \multirow{5}{*}{0,66} & \multirow{5}{*}{0,90} \\
\hline & AİÇ2 & 0,82 & & & \\
\hline & AİÇ3 & 0,85 & & & \\
\hline & AİÇ4 & 0,86 & & & \\
\hline & AİÇ5 & 0,85 & & & \\
\hline \multirow{4}{*}{ Algilanan Stres } & AS1 & 0,89 & \multirow{4}{*}{0,89} & \multirow{4}{*}{0,76} & \multirow{4}{*}{0,92} \\
\hline & AS2 & 0,89 & & & \\
\hline & AS3 & 0,81 & & & \\
\hline & AS4 & 0,89 & & & \\
\hline
\end{tabular}


Tablo 3. Yapısal Güvenilirlik ve Geçerlilik (Öğretmen Örneklemi)

\begin{tabular}{|c|c|c|c|c|c|}
\hline \multirow{2}{*}{$\begin{array}{l}\text { Algılanan İş } \\
\text { Verimliliği }\end{array}$} & AİV2 & 0,85 & \multirow{2}{*}{0,77} & \multirow{2}{*}{0,81} & \multirow{2}{*}{0,89} \\
\hline & AIV3 & 0,94 & & & \\
\hline \multirow{4}{*}{ Rol Çatışması } & RÇ1 & 0,77 & \multirow{4}{*}{0,69} & \multirow{4}{*}{0,51} & \multirow{4}{*}{0,81} \\
\hline & $\mathrm{RÇ} 2$ & 0,71 & & & \\
\hline & RÇ3 & 0,71 & & & \\
\hline & RÇ4 & 0,67 & & & \\
\hline
\end{tabular}

Öğretmen örnekleminin güvenilirlik ve geçerlilik sonuçlarının olduğu Tablo 3'e bakıldığında Cronbach's Alpha değerlerinin 0.69 ile 0.89 arasında, CR değerlerinin 0.70'in ve AVE değerlerinin 0.50'nin üzerinde olduğu görülebilir. $\mathrm{Bu}$ değerler uygun değerler olarak kabul edilir (Jung vd., 2017: 145).

3.4.3. Yapısal Model ve Standartlaştırılmış Yol Katsayıları

Banka çalışanları ve öğretmen örneklemleri için analiz sonuçlarına dair yol katsayıları, t-değerleri ve yapısal modeller sırasıyla Tablo 4, Şekil 2, Tablo 5 ve Şekil 3'te verilmiştir. Banka çalışanları örneklemi için ileri sürülen hipotezlerin tamamı desteklenmiştir. Banka çalışanları için yol katsayıları arasında, en yüksek değerin aile iş çatışması değişkeninin algılanan stres değişkeni üzerindeki pozitif etkisine ait olduğu görülmektedir. Aynı örneklem için ikinci en yüksek değer de aile iş çatışması değişkeninin algılanan iş verimliliği değişkeni üzerindeki negatif etkisine aittir. Hipotezi desteklenmesine rağmen en düşük yol katsayısı rol çatışması değişkeninin algılanan stres değişkeni üzerindeki etkisine aittir.

Tablo 4. Yol Katsayıları ve T-Değerleri (Bankacı Örneklemi)

\begin{tabular}{|c|c|c|c|c|}
\hline Hipotez & Yol & $\begin{array}{c}\text { Yol } \\
\text { Katsayısı }\end{array}$ & T-Değeri & Sonuç \\
\hline $\mathrm{H}_{1}$ & $\begin{array}{c}\text { Rol çatışması } \rightarrow \text { aile iş } \\
\text { çatışması }\end{array}$ & 0,31 & $3,192^{* * *}$ & $\begin{array}{c}\text { Hipotez } \\
\text { desteklendi }\end{array}$ \\
\hline $\mathrm{H}_{2}$ & $\begin{array}{c}\text { Rol çatışması } \rightarrow \text { algılanan } \\
\text { stres }\end{array}$ & 0,12 & $1,840^{*}$ & $\begin{array}{c}\text { Hipotez } \\
\text { desteklendi }\end{array}$ \\
\hline $\mathrm{H}_{3}$ & $\begin{array}{l}\text { Rol çatışması } \rightarrow \text { algılanan iş } \\
\text { verimliliği }\end{array}$ & $-0,29$ & $3,106^{* * *}$ & $\begin{array}{c}\text { Hipotez } \\
\text { desteklendi }\end{array}$ \\
\hline $\mathrm{H}_{4}$ & $\begin{array}{c}\text { Aile iş çatışması } \rightarrow \text { algılanan } \\
\text { stres }\end{array}$ & 0,66 & $8,493^{* * *}$ & $\begin{array}{c}\text { Hipotez } \\
\text { desteklendi }\end{array}$ \\
\hline $\mathrm{H}_{5}$ & $\begin{array}{c}\text { Aile iş çatışması } \rightarrow \text { algılanan } \\
\text { iş verimliliği }\end{array}$ & $-0,35$ & $3,308^{* * *}$ & $\begin{array}{c}\text { Hipotez } \\
\text { desteklendi }\end{array}$ \\
\hline $\mathrm{H}_{6}$ & $\begin{array}{c}\text { Algılanan stres } \rightarrow \text { algılanan } \\
\text { iş verimliliği }\end{array}$ & $-0,19$ & $1,741^{*}$ & $\begin{array}{c}\text { Hipotez } \\
\text { desteklendi }\end{array}$ \\
\hline \multicolumn{5}{|c|}{ Çift kuyruklu test için t-değerleri } \\
\hline \multicolumn{5}{|c|}{${ }^{*} 1.65$ (anlamlılık düzeyi=10\%) } \\
\hline \multicolumn{5}{|c|}{ ** 1.96 (anlamlılık düzeyi=5\%) } \\
\hline \multicolumn{5}{|c|}{${ }^{* * *} 2.58$ (anlamlılık düzeyi=1\%) (Hair vd., 2011: 145; Rezaei, 2015: 10) } \\
\hline
\end{tabular}

Şekil 2'de yer alan yapısal modele göre, algılanan iş verimliliği değişkeninin öncülleri arasında güçlü ilişkilerin olduğu görülmektedir. Algılanan 
Covid-19 Döneminde Evden Çalışmada Algılanan Işs Verimliliği ve Öncülleri Arasındaki İlişkiler: Banka Çalışanları ve Öğretmenler Üzerine Karşılaştırmalı Bir Araştırma

iş verimliliği açısından en güçlü yollardan birinin rol çatışması-aile iş çatışmasıalgılanan stres-algılanan iş verimliliği yolu olduğu, diğer önemli yolun da rol çatışması-aile iş çatışması-algılanan iş verimliliği yolu olduğu söylenebilir.

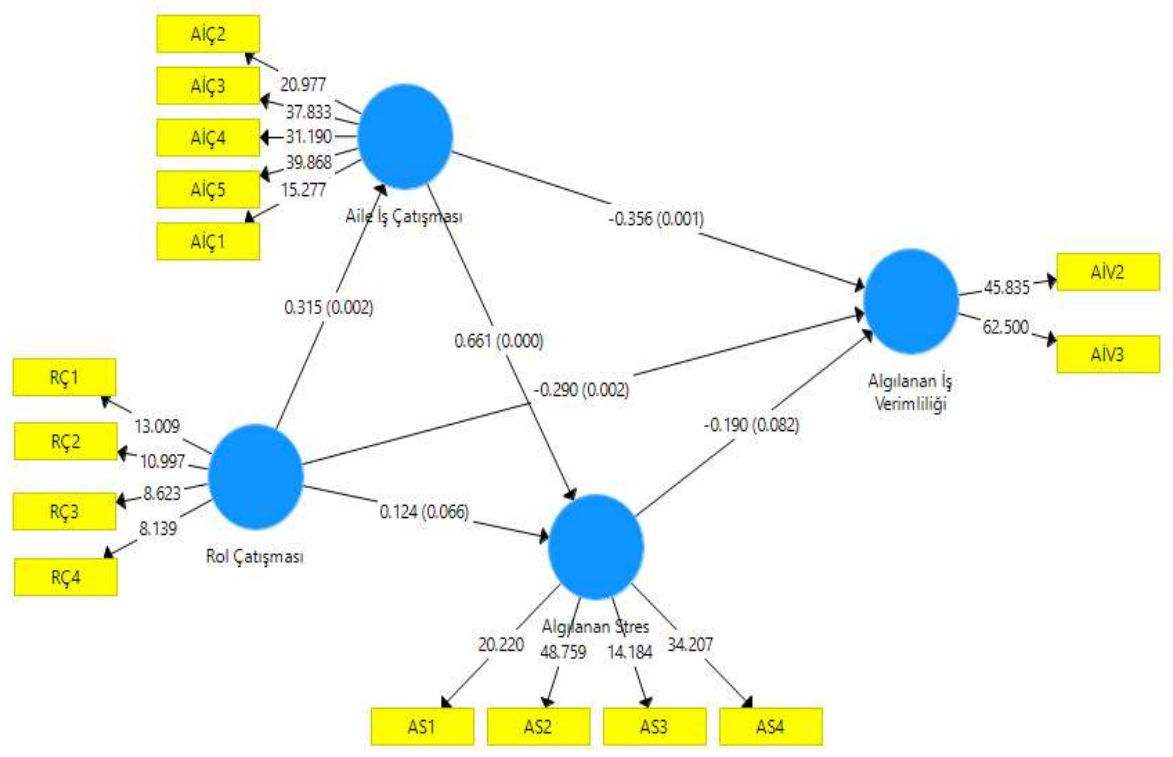

Şekil 2. Yapısal Model (Bankacı Örneklemi)

Öğretmen örneklemi için ileri sürülen hipotezlerden $\mathrm{H} 2$, H4 ve H6 desteklenmiştir. Tablo 5'e bakıldığında yol katsayıları arasında, en yüksek değerin aile iş çatışması değişkeninin algılanan stres değişkeni üzerindeki pozitif etkisine ait olduğu görülmektedir. Aynı örneklem için ikinci en yüksek değer de rol çatışması değişkeninin algılanan stres değişkeni üzerindeki pozitif etkisine aittir. Son olarak, öğretmen örneklemi için algılanan stres değişkeninin algılanan iş verimliliği değişkeni üzerindeki negatif etkisi, hipotez desteklendiği halde en düşük yol katsayısı olarak tespit edilmiştir.

Tablo 5. Yol Katsayıları ve T-Değerleri (Öğretmen Örneklemi)

\begin{tabular}{|c|c|c|c|c|}
\hline Hipotez & Yol & $\begin{array}{c}\text { Yol } \\
\text { Katsayısı }\end{array}$ & T-Değeri & Sonuç \\
\hline $\mathrm{H}_{1}$ & $\begin{array}{c}\text { Rol çatışması } \rightarrow \text { aile iş } \\
\text { çatışması }\end{array}$ & 0,11 & 1,013 & $\begin{array}{c}\text { Hipotez } \\
\text { desteklenmedi }\end{array}$ \\
\hline $\mathrm{H}_{2}$ & $\begin{array}{c}\text { Rol çatş̧ması } \rightarrow \text { algılanan } \\
\text { stres }\end{array}$ & 0,29 & $3,184^{* * *}$ & $\begin{array}{c}\text { Hipotez } \\
\text { desteklendi }\end{array}$ \\
\hline $\mathrm{H}_{3}$ & $\begin{array}{c}\text { Rol çatışması } \rightarrow \text { algıllanan iş } \\
\text { verimliliği }\end{array}$ & $-0,14$ & 1,359 & $\begin{array}{c}\text { Hipotez } \\
\text { desteklenmedi }\end{array}$ \\
\hline $\mathrm{H}_{4}$ & $\begin{array}{c}\text { Aile iş çatışması } \rightarrow \text { algılanan } \\
\text { stres }\end{array}$ & 0,43 & $5,930^{* * *}$ & $\begin{array}{c}\text { Hipotez } \\
\text { desteklendi }\end{array}$ \\
\hline
\end{tabular}


Tablo 5. Yol Katsayıları ve T-Değerleri (Öğretmen Örneklemi)

\begin{tabular}{|c|c|c|c|c|}
\hline $\mathrm{H}_{5}$ & $\begin{array}{c}\text { Aile iş çatışması } \rightarrow \text { algılanan } \\
\text { iş verimliliği }\end{array}$ & $-0,15$ & 1,469 & $\begin{array}{c}\text { Hipotez } \\
\text { desteklenmedi }\end{array}$ \\
\hline $\mathrm{H}_{6}$ & $\begin{array}{c}\text { Algılanan stres } \rightarrow \text { algılanan iş } \\
\text { verimliliği }\end{array}$ & $-0,22$ & 1,946 & $\begin{array}{c}\text { Hipotez } \\
\text { desteklendi }\end{array}$ \\
\hline \multicolumn{5}{|c|}{ 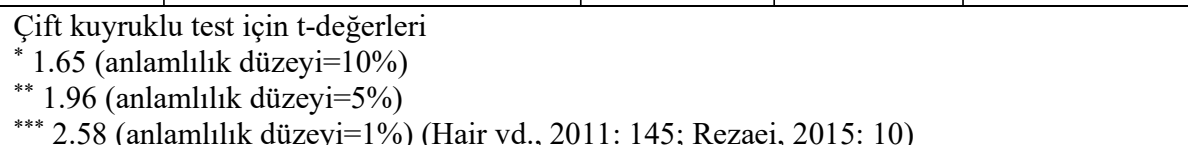 } \\
\hline
\end{tabular}

Şekil 3'te yer alan yapısal modele göre, algılanan iş verimliliği değişkeninin öncülleri arasında önemli bazı ilişkilerin olduğu görülmektedir. Algılanan iş verimliliği açısından en güçlü yollardan birinin aile iş çatışmasıalgılanan stres-algılanan iş verimliliği yolu olduğu, diğer önemli yolun da rol çatışması-algılanan stres-algılanan iş verimliliği yolu olduğu söylenebilir.

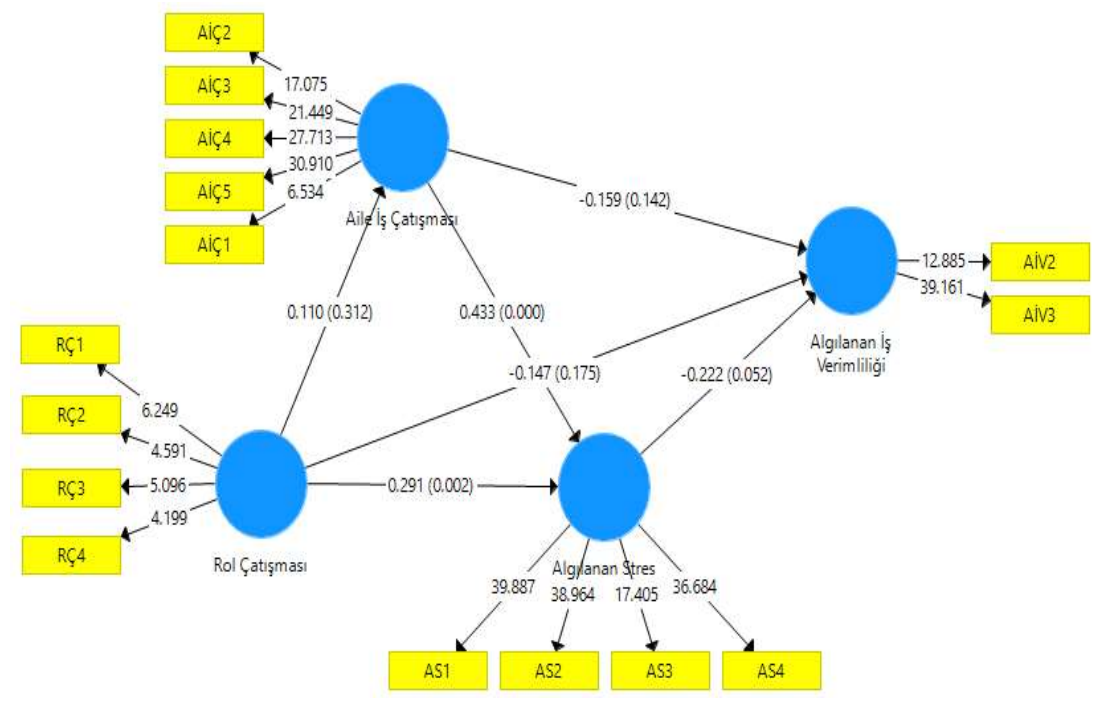

Şekil 3. Yapısal Model (Öğretmen Örneklemi)

\section{Sonuç}

Bu çalışmada COVID-19 döneminde evden çalışmış veya çalışmakta olan banka çalışanları ve öğretmenler için algılanan iş verimliliği ve öncülleri olan aile iş çatışması, rol çatışması ve algılanan stres arasındaki ilişkiler yapısal eşitlik modelleme ile test edilmiş ve çıkarımlarda bulunulmuştur. Örneklem olarak öğretmen ve banka çalışanlarının seçilmesinin sebebi, Türkiye'de pandeminin etkisinin başladığ 2020 yılının Mart ayının başlarından itibaren daha önce evden çalışma sisteminin tercih edilmeyip, bir anda evden çalışma sistemine kısmen de olsa geçilmesidir. Dolayısıyla öğretmen ve banka çalışanları için yeni bir çalışma 
Covid-19 Döneminde Evden Çallşmada Algllanan İş Verimliliği ve Öncülleri Arasindaki Ilisşkiler: Banka Çalışanları ve Öğretmenler Üzerine Karşılaş̧tırmalı Bir Araş̧tırma

sistemi olarak ifade edilebilir. Banka çalışanları belirli bir dönem, MEB’e bağlı öğretmenler de aralıklarla ve çoğunlukla evden çalışma yapmaktadırlar.

Banka çalışanları örneklemi için elde edilen bulgular incelendiğinde, algılanan iş verimliliğinin en önemli öncülünün $-0,35$ yol katsayısı ile aile iş çatışması olduğu görülmektedir. Çalışanın ișe ilişkin sorumluluklarının ailevi sorumluluklar nedeniyle yerine getirilmesinde yaşanan zorluk olarak tanımlanan aile iş çatışması özellikle pandemi döneminde evden çalışmada en önemli etken olarak tespit edilmiş̧ir. Algılanan iş verimliliğinin ikinci önemli öncülü -0,29 yol katsayısı ile rol çatışması, üçüncü önemli öncülü ise $-0,19$ yol katsayısı ile algılanan strestir. Araştırma sonuçlarına göre, algılanan stresin pandemi dönemi için en önemli öncülü aile iş çatışmasıdır.

Öğretmen örneklemi için elde edilen bulgular incelendiğinde, algılanan iş verimliliğinin en önemli öncülünün $-0,22$ yol katsayısı ile algılanan stres olduğu tespit edilmiştir. Algılanan stresin öncüllerine bakıldığında en önemli öncülün 0,43 yol katsayısı ile aile iş çatışması ve 0,29 yol katsayısı ile rol çatışması olduğu bulunmuştur. Öğretmen örneklemi için ileri sürülen hipotezlerden 2,4 ve 6 nolu hipotezlerin desteklendiği görülmektedir.

Her iki örneklem için elde edilen bulgular birbirinden farklılık gösterse de, önemli benzerlikler mevcuttur. Her iki örneklem grubu için de yol katsayıları farklı da olsa aile iş çatışması ve rol çatışması değişkenlerinin algılanan iş verimliliği açısından son derece kritik öneme sahip olduğu açıktır. Dolayısıyla insan kaynakları yöneticilerinin ve genel olarak tüm yöneticilerin bu iki değişkeni dikkate alması gerekmektedir.

Çalışanın uyuşmayan iş gereksinimleri ile karşılaştığında, yapmak istemediği faaliyetler yapması gerektiğinde ve bu faaliyetlerin işinin bir parças olduğunu düşünmediğinde ortaya çıkabilen rol çatışmasının, çalışanların işlerini planlayan, görev veren ve işlerini denetleyen ilk kademe yöneticiler ve insan kaynakları yöneticileri tarafindan dikkate alınarak mümkün olduğunca oluşmaması sağlanmalıdır. Bu nedenle evden çalışma sistemine uygun bir iş tanımı yapılmış olmalı, ofis ortamında olduğu gibi çalışmanın tüm süreci açık bir şekilde tanımlanmalı, çalıșandan çalıșmasının beklendiği saatler yazılı bir șekilde bildirilmeli, süreç bilgi boşluğu bırakılmayacak şekilde tasarlanmalı ve tüm çalışanlarla paylaşılmalıdır. Özellikle pandemi döneminde evden çalışma ortamında çalışanların yöneticileriyle iletişim kanalları açık ve şeffaf olmalıdır.

Gerek banka çalışanları gerekse de öğretmen örneklemi için insan kaynakları yöneticileri iş analizlerini evden çalışma sistemini dikkate alarak yeniden yapmalıdırlar. Çünkü işyerinde çalışma ile evden çalışma koşulları arasında önemli bir fark olacaktır. İsyerinde çalıșma sisteminde dahi rol çatışması sık yaşanabilirken, evden çalışma sisteminde aynı düzeyde dahi yaşansa rol çatışmasının algılanan strese, aile iş çatışmasına ve algılanan iş verimliliğine 
etkisi daha büyük olabilir. Rol çatışması en aza indirgendiğinde aile iş çatışması ve algılanan stresin oluşumu da azaltılmış olacaktır. Aile iş çatışmasının minimuma inmesi için evden çalışma sistemine özgü bir esneklik çalışanlara sağlanmak zorundadır. Bireyin işyerinde olduğu zamanlarda dahi önemli olan aile iş çatışmasının evden çalışma sisteminde özellikle çocuklu ve/veya eşi de çalışan bireylerde çok daha fazla etkili olacağı göz önünde bulundurularak çalışanlara karşılaşacakları durumlarla ilgili alternatif çözüm yolları üretilmeli ve evden çalışma sistemi bu durum değerlendirmelerine göre yeniden yapılandirılmalıdir.

Evden çalışma sisteminin başarı ile sürdürülmesinde en önemli görev kuşkusuz yöneticilere düşmektedir. Dengeyi doğru kurabilmek en önemli konulardan biridir. Bu noktada, örneğin çalışanları uygun bir iş-yaşam dengesini korumaya teşvik etmek büyük önem taşımaktadır (Deloitte, 2020: 15). Evden çalışma sürecinde çalışanlar kendi kontrollerinde olmayan pek çok nedenle (örneğin ev işleri, çocuk bakımı, vb.) çalışmaya ara vermek zorunda kalabilmekte ve iş-yaşam dengesi sorunları yaşayabilmektedirler. Bu zorlu süreçte, çalışanlarla kurulan güçlü iletişim ve esneklik sağlanması ile çalışanların iş yaşam dengelerini kurmalarını teşvik etmek onların verimliliklerini ve iş tatminlerini olumlu yönde etkileyecektir. Evden çalışma sisteminin çalışan üzerinde yaratacağı uzun dönemli etkiler ve küresel salgının henüz bitmediği göz önünde bulundurularak stratejiler geliştirilmelidir (Arıkboğa vd., 2020: 31-32). Bu bağlamda, evden çalışmada, insan kaynakları uzmanlarının bakış açısıyla çalışan refahının ve işyaşam dengesinin korunması gerekir. Ayrıca, İK yöneticileri evden çalışma için oluşturacakları insan kaynakları politikaları ile aynı anda dijital geçiş ve iş hayatı dengesi için yollar da açmalıdır (Gigauri, 2020: 4).

İnsan kaynakları yönetimi alanının ileride de muhtemel bazı sebeplerle (benzer bir pandemi, maliyet tasarrufu vb. nedenlerle) evden çalışma sistemine özgü olarak çalışma alanlarını uyarlaması ve yeni araştırmalar yaparak iş verimliliğini nasıl arttırabileceğini düşünmesi gerekmektedir. İşletmelerin politikalarını ve prosedürlerini tekrar gözden geçirerek evden çalışma sisteminde mükemmel bir çalışan deneyimi oluşturmaya yönelmeleri çalışan verimliliklerini arttıracaktır. Çünkü, yukarıda belirtilen sebeplerin dışında her an oluşabilecek sebepler nedeniyle (örneğin, çocuğunun veya ebeveyninin hasta olması, onlarla kısa süreli de olsa ilgilenmesi gerektiği durumlarda) dahi evden çalışma sistemi önem taşımaktadır. Ayrıca, işletmelerin iletişim stratejilerini ve araçlarını hibrid bir işgücünü düzenlemek için uyarlamalarında yarar vardır. Dolayısıyla da iş gücü verimliliği ölçütlerinin de tekrar değerlendirilmesinde, en azından işte geçirilen zamandan çok sonuçlara odaklanılması yerinde olacaktır. Özetle, insan kaynakları yönetimi çalışanlarına en iyi çalışma çevrelerini oluşturmaları için özgürlük sunmalı ve yeni çalışma sisteminin tasarlanmasında çalışanlarının da görüsslerini almalıdır. 
Covid-19 Döneminde Evden Çallşmada Algllanan İş Verimliliği ve Öncülleri Arasindaki İlişkiler: Banka Çalışanları ve Öğretmenler Üzerine Karşılaş̧tırmalı Bir Araştırma

Her çalışmada olduğu gibi bu çalışmanın da kısıtlamaları mevcuttur. Çalışmanın ilk kısıtlaması araştırma modelini oluşturan değişkenler ile ilgilidir. Yapılacak güncel literatür taraması sonucunda araştırma modeline farklı değişkenler de ilave edilmesi mümkündür. Gelecekte yapılacak çalışmaların, bu hususu dikkate alması önerilmektedir. İkinci bir kısıtlama ise araştırma örneklemidir. Araştırma yalnızca Bursa il merkezinde öğretmenler ve banka çalışanlarını içermiştir. Dolayısıyla sonuçların Türkiye örneklemine genelleştirilmesine ihtiyatla yaklaşılmalıdır. Ayrıca, evden çalışmayı deneyimleyen özel sektör firmalarının çağrı merkezi çalışanları da araştırmaya dâhil edilmesi gelecekte yapılacak çalışmalar için önemli bir tavsiye olacaktır.

\section{Kaynaklar}

Arıkboğa, F., Doğan, E., Akdöl, B. ve İrengün, O. (2020), Küresel Salgın Döneminde Evden Çalışma Araştırma Raporu, 07 Mart 2021 tarihinde https://cdn.istanbul.edu.tr/FileHandler2.ashx?f=kuresel-salgindoneminde-evden-c\%CC\%A7alis\%CC\%A7ma-aras\%CC\%A7tirmaraporu.pdf adresinden alındi.

Aydın, G. G. ve Ünnü, N.A. (2020), Örgütsel Aile Desteği, İş-Aile Çatışması Ve İşle Bütünleşme Arasındaki İlişkileri Belirlemeye Yönelik Bir Araştırma. Erciyes Üniversitesi Sosyal Bilimler Enstitüsü Dergisi, (48), 9-53.

Carnevale, J. B. ve Hatak, I. (2020), Employee Adjustment and Well-Being in the Era of COVID-19: Implications for Human Resource Management, Journal of Business Research, (116), 183-187.

Chadee, D., Ren, S. ve Tang, G. (2021), Is Digital Technology the Magic Bullet for Performing Work at Home? Lessons Learned for Post COVID-19 Recovery in Hospitality Management, International Journal of Hospitality Management, (92), 1-8.

Colombo, L. ve Ghislieri, C. (2008), The Work-to-Family Conflict: Theories and Measures, TPM (Testing, Psychometrics, Methodology in Applied Psychology), 15(1), 35-55.

Deloitte (2020), İşin Geleceği: Uzaktan Çalışma Sisteminde Organizasyonel Dayanıklılı̆̆1 Korumak, Deloitte Raporu, 1-17, 15 Nisan 2021 tarihinde https://www2.deloitte.com/content/dam/Deloitte/tr/Documents/humancapital/isin-gelecegi-uzaktan-calisma-sisteminde-organizasyoneldayanikliligi-korumak.pdf adresinden alındı.

Dockery, M., ve Bawa, S. (2020), Working from Home in the COVID-19 Lockdown. Bentley: Bankwest Curtin Economics Centre, 1-5, 03 Nisan 2021 tarihinde https://bcec.edu.au/assets/2020/05/BCEC-COVID19Brief-4_Working-from-home.pdf adresinden alındı. 
Feng, Z. ve Savani, K. (2020), Covid-19 Created a Gender Gap in Perceived Work Productivity and Job Satisfaction: Implications for Dual-Career Parents Working from Home. Gender in Management: An International Journal, 35(7/8), 719-736.

Firat, Z. M. ve Cula, S. (2016), İş-Aile Çatışması, Aile-İş Çatışması ve İş Doyumunun Öğretmenlerin Yaşam Doyumu Üzerindeki Etkisi. Başkent University Journal of Education, 3(2), 146-155.

Gigauri, I. (2020), Effects of Covid-19 on Human Resource Management from the Perspective of Digitalization and Work-life-balance. International Journal of Innovative Technologies in Economy, 4 (31), 1-10.

Giurge, L. M. ve Bohns, V. K. (2020), 3 Tips to Avoid WFH Burnout, 03 Nisan 2021 tarihinde https://hbr.org/2020/04/3-tips-to-avoid-wfh-burnout adresinden alınd.

Hair, J. F., Ringle, C. M. ve Sarstedt, M. (2011), PLS-SEM: Indeed a Silver Bullet, Journal of Marketing Theory and Practice, 19(2), 139-152.

Jung, J., Han, H. ve Oh, M. (2017), Travelers' Switching Behavior in the Airline Industry from the Perspective of the Push-Pull-Mooring Framework, Tourism Management, (59), 139-153.

Küçükusta, D. (2007), Konaklama işletmelerinde iş-yaşam dengesinin çalışma yaşamı kalitesi üzerindeki etkisi, Yayımlanmamış Doktora Tezi, İzmir: Dokuz Eylül Üniversitesi Sosyal Bilimler Enstitüsü.

Lee, E. H. (2012), Review of the Psychometric Evidence of the Perceived Stress Scale, Asian Nursing Research, 6(4), 121-127.

Mustajab, D., Bauw, A., Rasyid, A., Irawan, A., Akbar, M. A., ve Hamid, M. A. (2020), Working from Home Phenomenon as an Effort to Prevent COVID19 Attacks and its Impacts on Work Productivity. TIJAB (The International Journal of Applied Business), 4(1), 13-21.

Netemeyer, R. G., Brashear-Alejandro, T., ve Boles, J. S. (2004), A CrossNational Model of Job-Related Outcomes of Work Role and Family Role Variables: A Retail Sales Context. Journal of the Academy of Marketing Science, 32(1), 49-60.

Parvaiz, L., Batool, S., Khalid, A., ve AftabFarooqi, Y. (2015), Impact of Stressors (Role Conflict, Role Overload, Leadership Support and Organizational Politics) on Job Stress and its Subsequent Impact on Turnover Intention, International Journal of Business and Management Invention, 4(10), 52-63. 
Covid-19 Döneminde Evden Çallşmada Algllanan İş Verimliliği ve Öncülleri Arasindaki Iliş̧kiler: Banka Çalışanları ve Öğretmenler Üzerine Karşılaş̧tırmalı Bir Araştırma

Rezaei, S. (2015), Segmenting Consumer Decision-Making Styles (CDMS) toward Marketing Practice: A Partial Least Squares (PLS) Path Modeling Approach, Journal of Retailing and Consumer Services, (22), 1-15.

Schieman, S., Badawy, P. J., Milkie, M. A. ve Bierman, A. (2021), Work-Life Conflict During the COVID-19 Pandemic. Socius, (7), 1-19.

Soto-Rubio, A., Giménez-Espert, M. D. C. ve Prado-Gascó, V. (2020), Effect of Emotional Intelligence and Psychosocial Risks on Burnout, Job Satisfaction, and Nurses' Health During the COVID-19 Pandemic, International Journal of Environmental Research and Public Health, 17(21), 1-14.

Taylor, J. M. (2015), Psychometric Analysis of the Ten-Item Perceived Stress Scale. Psychological Assessment, 27(1), 90.

Tentama, F., Sukesi, T. W., Mulasari, S. A. ve Sulistyawati, S. (2019), The Role of Work Motivation and Work Support and Their Implication Towards Work Productivity in Woman Workers, International Journal of Research Studies in Management, 8(2), 1-9. 